\title{
Analysis of the Condition and Development Opportunities of Cave Tourism in Primorsko-Goranska County
}

\author{
Rade Knežević* \\ Renata Grbac Žiković** \\ Received: ???? 2010| Accepted: ???? 2010
}

\section{Abstract}

This paper examines caves as morphological factors of tourism development in Primorsko-Goranska County. The primary aim is to promote cave heritage parallel with the development of cave tourism. The methodological framework is based on analysing material in the archives of tourist boards, taking an inventory of cave resources (case study), conducting interviews, and making a SWOT analysis of cave tourism development.

Research results show that caves represent a complex resource in the tourist trade of Primorsko-Goranska County, to which little importance has been attached up to date (priority being given to mass tourism).

In the context of tourism development, caves fall into four groups. The first group comprises caves that have a long tradition, but show signs of aging as a tourism product. The second group include caves that were once open to the public, but were later closed for some reason. The third group consists of caves on the seaside or seabed visited by speleologists-divers. The fourth group is made up of potential cave sites that have been evaluated as being attractive, but are located in hard-to-access areas, making their valorisation in tourism purpose more difficult.

Only Lokvarka Cave has a substantial influence on the development of special interest tourism in Lokve, while in all other cases, the role of caves in the tourism offering needs to be revalorised.

Key words: cave tourism, Primorsko-Goranska County, caves, development, carbonates bedrock.

\footnotetext{
* Ph.D., Associate Professor, Faculty of Tourism and Hospitality Management Opatija, University of Rijeka, e-mail: radek@fthm.hr

** Assistant, Faculty of Tourism and Hospitality Management Opatija, University of Rijeka,

e-mail: renatag@fthm.hr
} 


\section{Introduction}

Cave tourism is a fairly recent name given to tourism that involves speleological structures ${ }^{1}$. As a form of special interest tourism, cave tourism can be found in the tourism offerings of Brazil (Resende, 2005), Indonesia (All-Asia touristic) ${ }^{2}$, Russia (www.russiantraveller.ru), ${ }^{3}$ Romania (Travel Romania, 2OIO), Kyrgyzstan (http://www.kyrgyzjer.com/en/Tourism/ section $)^{4}$ and other countries in which carbonate relief is widespread. ${ }^{5}$ Because of some of the features of its offering (labyrinths, narrow passages, high humidity and the lack of natural light), this form of tourism has been included in adventure tourism or rural tourism (National Caves Association, 2OIO) in certain countries with karst relief, (USA ${ }^{6}$, Austria, Italy, France, Spain, Mexico).

The earliest written documents concerning the manifestations of tourism, as well as the oldest knowledge of Croatian caves, can be found in the work of Roman scholars such as Lucretius, Strabo and Pliny. The second oldest document is a church scroll dating back to IO96 and illustrating a pechina (cave) on the island of Ugljan near Zadar. The year I886 is considered the beginning of the development of cave tourism, including promotional activities. This is the year the Samogradska Cave Committee (Perušić) was established to make the cave accessible to visitors. By I889, the cave was already illuminated and ready for visitors (Blažević, Knežević, 2006). The first speleological society in Croatia was founded in I892, and it made Baraćev Cave a part of the tourism offering of the Plitvice Lakes (Kovačević, 20O3).

A turning point came in I899, the year that Dragutin Gorjanović-Kramberger discovered the cave of prehistoric man, known as Homo sapiens neanderthalensis on Hušnjakov Hill. Later, the site was classified as one of the most valuable Neanderthal sites in the world, and the cave has become a major tourist destination in Croatia.

In the early twentieth century, speleological research, including the elaboration and publication of topographic maps and professional studies, as well as professional and scientific papers, was intensified. By the end of the century, a total of 55 caves more than I,OoO metres in length and 54 pits more than 250 metres in depth were registered in Croatia. The greatest lengths (I6,396 metres) were measured in the cave system of Đulin ponor - Medvedica, located in the Ogulin-Plaški valley.

A few of the longest caves (Ponor Vele Vode I,495 m, Hajdova Hiža I,I88 m, the Kicljeve pit system I,O75m) and the deepest pits (Stupina jama - 4I3m, Jarmovac - 3OIm, Kame Hame $-263 \mathrm{~m}$ ) are located within the territory of the County. Not one of these structures, however, is connected with tourism.

1 The term "speleological structure" is linked to the Ancient Greek word spelaion meaning a natural underground cavity. In a broader sense, all natural underground cavities are considered to be speleological structures. However, since speleological structures are largely tied to karst areas and are created as a result of karstic processes, in a more narrow sense, they are considered to be underground cavities in karst (karst caves or common caves). According to the International Union of Speleology, a speleological structure is a natural underground cavity in karst, of a minimum depth or length of five metres, into which a person can enter (Bočić, 2005).

2 The German tour operator specialised in individual excursions to Asia: O3/IO/2OOO.

3 Original Russian text: Спелеотуризм в России, I3.О2.2009.

4 Under the selective group of Special Interest Tourism

5 Carbonate rock, one of the major preconditions for the formation of speleological structures, can be found in 60 countries around the world.

${ }^{6} 20 \%$ of the country's area is covered in karst terrain. 
Fifteen caves (Baraćeve špilje, Baredine, Biserujka, Cerovačke špilje, Feštinsko kraljevstvo, Grapčeva špilja, Grgosova špilja, Golubnjača, Lokvarka, Manita peć, Modra špilja, Samograd, Veternica, Vranjača, Vrelo), and two tunnel shelters (an ancient underground water-supply system in Novalja known as "Talijanska buža”, and the Bunkeri tunnel shelter at Paklenica) are on the list of Croatian show caves.

Despite speleological research and resource characteristics, caves in Croatia are seen in scientific and professional literature as being in the initial phase of valorisation in tourism purposes, although a significant improvement has been observed relative to previous years (Žanetić, 2009). Similar evaluations of the condition and development stage of cave tourism in Croatia can be found in the work of other authors (Božić, I999; Buzjak, 2008), as well as in studies conducted by tourism enterprises (Karlovac County Tourist Board, 2009).

According to research carried out in drawing up the Spatial Plan of Primorsko-Goranska County (200O), there are 2IO speleological structures of various forms located within the County's territory $\left(3,582 \mathrm{~km}^{2}\right)^{7}$ Three caves (I.4\%) are being used for conventional tourism purposes, while a number of other caves serve as bases for scientific research and sports activities. $^{8}$

The hypothesis formulated states that cave tourism is capable of generating development and influencing the structures and processes which change the functional characteristics of the County's insufficiently developed areas. To this end, cave heritage has been researched, together with the attracting force of cave tourism.

\section{Methodology framework}

In analysing the development of caves as tourism resources, the focus of attention was on the mountain region of Primorsko-Goranska County. This region lacks development opportunities in other economic branches, leaving tourism as its greatest opportunity for development. Field studies of the caves Zamet, Lokvarka, Hajdova Hiža, Muževa, Medvjeđa, Biserujka, Vrelo, Bukovac and Vrata (cavern) have been conducted over a period of years, making later analyses easier and providing a better understanding of spatial relationships.

The field studies did not require any special speleological abilities or equipment as these caves have marked paths and facilities that ensure safe movement. Research also included the ice cave on Jarmovac and Pilar Ice Cave in Mrzle Drage. These ice caves have daylight illumination, making it easier to monitor natural parameters.

Data regarding tourism traffic (visitor numbers) were taken from the archives of the concession holders responsible for managing caves in recent years. Bio speleological, hydrographical, geological, archaeological and other professional and scientific data have been taken from CRO-SPELEO, the scientific and professional database concerned with speleological structures in the territory of Croatia.

7 M. Matas (2009) classifies subterranean karst forms as pits (having vertical passages), caves (primarily developed in a horizontal direction), caves (cavities or shelters at the bottom, or in the sides, of rocky cliffs) and caverns (underground cavities that are not connected with the surface). The total number of speleological structures does not include caverns, discovered by recent construction works, or speleological structures located in the County's marine area $\left(4,398.64 \mathrm{~km}^{2}\right)$.

8 There is no official definition of cave-tourism phenomenon in Croatia. Hence, the literature relies on V. Božić (I999) who argues that a show cave must possess aesthetic, historic, scientific and educational value, as well as the possibility of organising visits. 
According to the constitutive subjects of the tourist market (tourism supply and tourism demand) and their economic effects', caves can be classified into four groups.

The first group comprises speleological structures that have a market tradition (Lokvarka Cave at Lokve,Vrelo Cave at Fužine, and Biserujka Cave on Krk Island). Cave tourism in these caves began to develop in the early twentieth century, and as a tourism product, it is showing signs of aging (no significant change in the capacity utilisation of the tourism offering, while tourism spending stagnates; the derived tourism offering shows no change relative to earlier years).

The second group involves speleological structures that have been static and have responded poorly to change, causing them to lose their tourism-related function (Hajdova Hiža Cave near Guče Selo, Zamet Cave in Rijeka, Bukovac Cave near Sunger, Pilar Ice Cave near Mrkopalj, Škodovnik Ice Cave). Great destruction has been caused to the structures belonging to this group. They have been used as dump sites, and their walls are covered in graffiti or in soot from torches used for lighting.

Speleological structures located on the seaside belong to the third group (Pijavica Cave not far from Senj, Medvjeđa Cave near Lošinj, Vrbnik Cave, Srakane Cave, the cave system of Medova Buža near Lopar, Prvić tunnel). Speleologist-divers visit these caves. Diving in underwater caves, linked to diving tourism, is becoming more and more popular, and its market is rapidly growing (a 9\% growth rate after 1999).

The fourth group consists of speleological sites that have potential (Golubinja Cave and Medvjeđa Cave near Lokve) and sites that need to undergo restructuring (Zamet Cave, Hajdova Hiža Cave, Pilar Ice Cave and Bukovac Cave).The problem is that certain caves, designated as potential resources, are located in inaccessible areas and require the construction of new roads leading to them.

\section{Factors of karstification}

The formation of speleological structures in soluble rock is the result of interdependent factors such as lithological composition, water circulation along fractures, climate- and biologyrelated factors, tectonics (fault plates) and chemical processes.

The rock composition of Primorsko-Goranska County (Basic Geological Map, 1985) is largely made of carbonates, in which prevails Jurassic and Cretaceous limestones (88\%) and Palaeogene limestone breccia (8\%).The County's mountain part forms a broad anticline, and its coastal region, a syncline. Limestones, consisting largely of calcium, are pure in mountain areas (the Bijele Stijene site has a purity of 99.3), resulting in white speleothems ${ }^{10}$ (stalactites, stalagmites, curtains, flowstone). It has been observed that speleothems in caves located along mountain edges may be brown due to mixtures of bitumen, while speleothems in coastal caves may be reddish due to mixtures of iron oxide-hydroxide (in particular, speleothems in Biserujka Cave). In Primorsko-Goranska County, marketers of cave tourism have not, up to date, made use of these differences in speleothem colours as an attraction for visitors, that is, as a feature of the tourism product.

9 A. Petrović (2006) classifies caves according to hydrographic features (river caves and dry caves), according to origin (anthropogenic, volcanic, artificial, karstic, abrasive and thermal caves), and according to geomorphological features (coastal, hanging, cascade, crater and littoral caves).

10 Speleothems are secondary chemical deposits formed by water. 


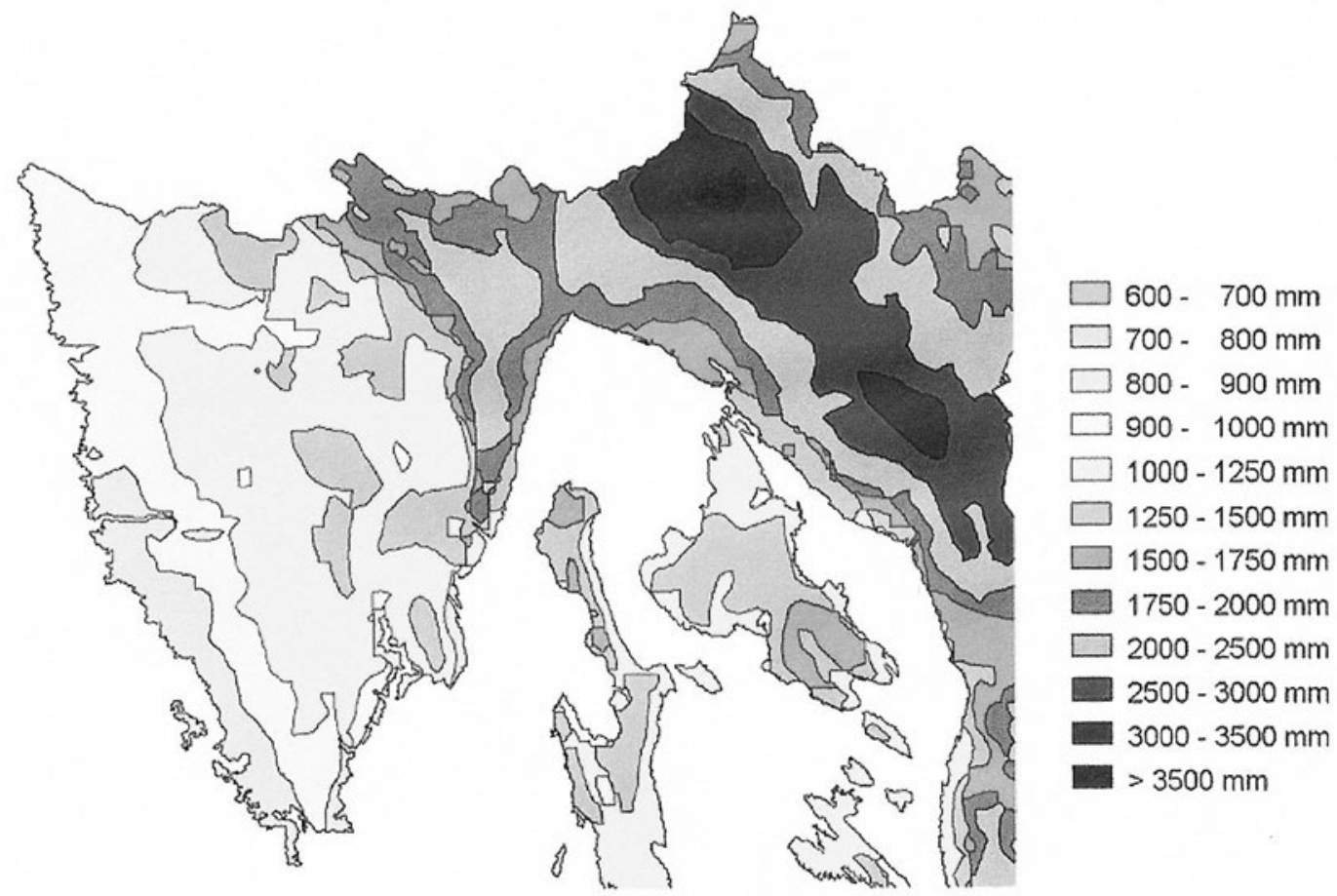

Figure 1 Average annual amounts of precipitation in Primorsko-Goranska County

Source: Rubinić, J., 2004.

The carbonate rocks are about seven kilometres thick (Basic geological map, 1985). Thicker strata are separated into smaller blocks among which cavities (caverns) of various sizes have been formed. Such structural relations have been confirmed during the building of tunnels and other types of construction work. Particular examples of caverns are Vrelo (discovered in 1950 during the construction of the Bajer storage lake), Učka (discovered in 198I during tunnel construction) and Vrata (discovered in 2008 during tunnel construction).The greatest attraction is the Učka cavern which is also a water reservoir (it dries out in summer), and it is used to supply the Liburnia Riviera with water. The Vrelo cavern is being used for tourism purposes. A bridge has been built over the Vrata cavern, and its attraction is that it is one of a kind in the world. The level of karstification, together with the number and heterogeneity of speleological structures, depends upon precipitation and the hydrologic cycle $\left(\mathrm{CO}_{2}\right.$ intensifies the dissolution of carbonate rock).

Local amounts of precipitation (and its aggregate state) are associated with the influence of westerly winds and elevation above sea level (Fig. I).

The interdependency of the amount of precipitation and the number of speleological structures is evident in the County's territory. This means that the greatest concentration of karstic features can be found in the upper parts of the mountains Snježnik (I,506 m), Risnjak (I,529 m), Viševica (I,428 m), Bijele Stijene (I,335 m) and Bjelolasica (I,533 m).Because sites located in these parts are not easily accessible, they are more suited to the development of adventure cave tourism rather than conventional cave tourism.

Where the range of the karst relief is concerned, it should be noted that karst landscape is not the only landscape feature of the County's broader geographical position. Its speleo- 


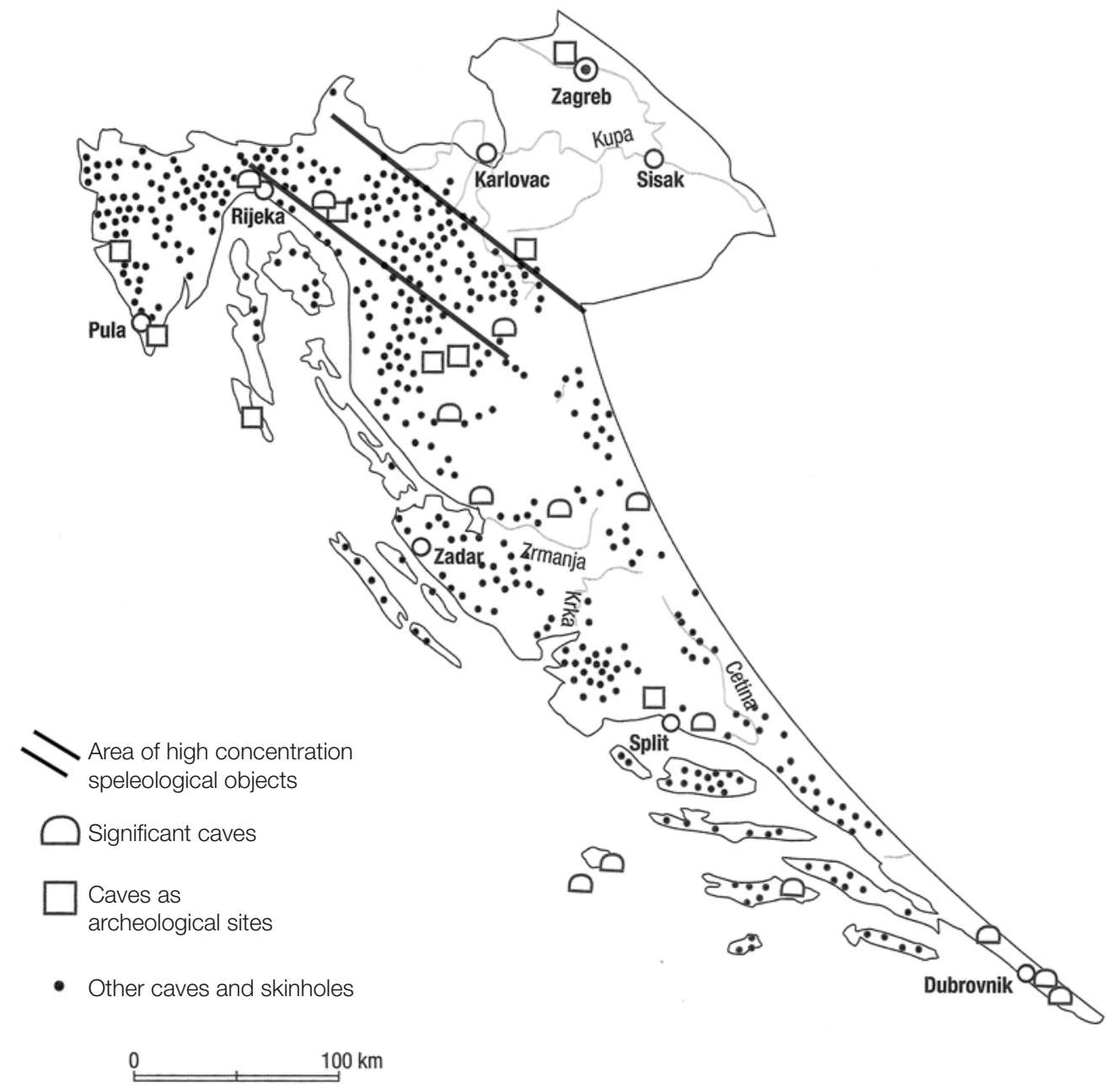

Figure 2 Distribution of speleological structures in Croatia

Source: Matas, 2009.

logical morpho-structure is part of the broader Dinaric karst which contains some 20,000 subterranean structures (Matas, 2009) (Figure 2).

The situation on the cave-tourism market, therefore, requires efforts in successfully dealing with competitors and ensuring long-term sustainable participation in this market.

\section{Structure and attributes of the cave-tourism offering of Primorsko-Goranska County}

The geographic and tourism-related segmentation of cave-tourism resources is based on the potential and real role of caves in the tourism offering. Data on visitor numbers and revenue have been used as relevant indicators.

The collective data on visitor numbers show that the number of visitors in a year ranges between 30 and 45 thousand (Figure 3 ). 


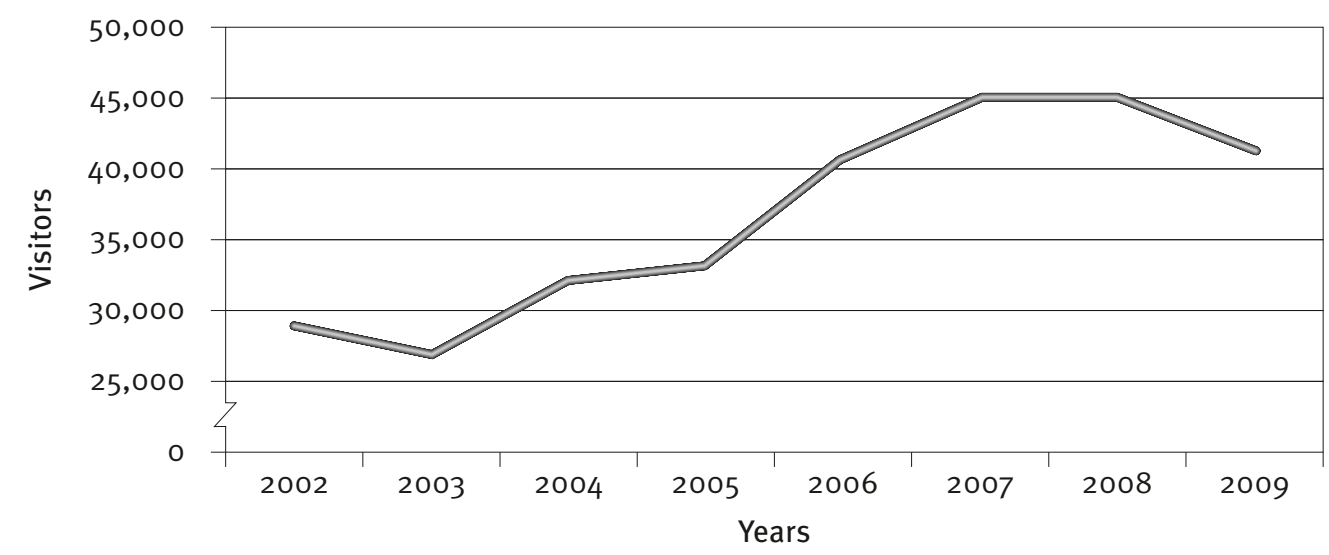

Figure 3 Number of visitors to caves in Primorsko-Goranska County (2002 - 2009)*

Source: Archives of Šiloturist Travel Agency, Fužine Tourist Board, Lokve Tourist Board

* Data relate to Vrelo Cave at Fužine and Biserujka Cave. In the observed period, an annuity amounting to a flat turnover created by 2,500 visitors was paid by the concession holder of Lokvarka Cave.

The differences in visitor numbers by cave are substantial. The level of tourism development of the areas in which caves are located has a greater influence on visitor numbers than the size of the caves and the duration of tours to the caves.

Being natural resources, the caves are managed by the Public Institution "Priroda", registered for the management of protected nature areas. "Priroda" grants concessions for cave management to public or private enterprises. Details pertaining to cave management are set out in Article 7I, Item 2 of the Nature Protection Act (Official Gazette No. 7O/O5). Concession holders are responsible for marketing-related matters, cave maintenance and promotion, and it is here that problems arise (how to gain maximum profits with minimum investment).

\section{Operational cave-tourism structures}

Lokvarka Cave at Lokve,Vrelo Cave at Fužine and Biserujka Cave on Krk Island have continued to operate over the years.

There are a number of landmarks in the history of Lokvarka Cave: I9II - when the cave was discovered, I9I2 - when visits and research activity began, and I935 - when the commercial exploitation of the cave began, after a reconstruction of paths within the cave. Several more times, railings were replaced, repairs made, and cave studies conducted, and as a result the cave remained technically inactive for about three years. Despite a variety of difficulties, the cave has managed to survive on the tourist market, a feat which some of the larger and better known caves have not been able to accomplish. There are a number of reasons for this, the main ones being:

- the morphological, geological and hydrological condition of the cave (Figure 4)

- the open view of passages and domination over cave horizon (educational basis)

- the vicinity of major roads and the permanent settlement of Lokve

- the interpolation of other parts of the tourism offering (Golubinjak Forest Park, Lokvarka Lake) 


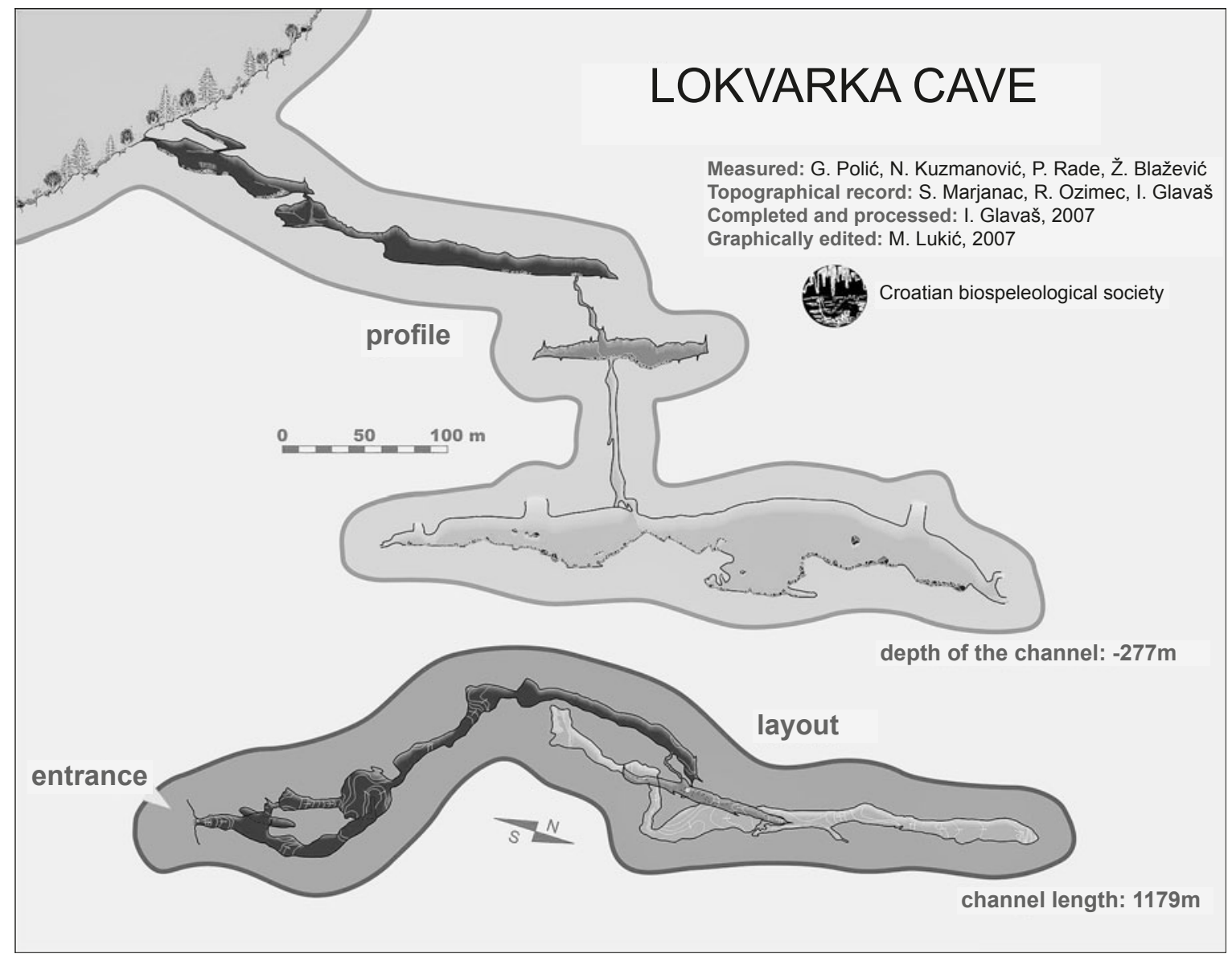

Figure 4 Profile of Lokvarka Cave

Source: Ozimec, 2007.

- tradition, through which a well-trained guides have emerged

- well-protected interior (in I961, the cave was proclaimed a geomorphological monument of nature)

- an optimum cave tour in terms of time and physical requirements (2,762 visitors toured the cave in 2009).

- the cave has become a brand in the tourism trade of Lokve.

The problems that the cave faces are linked to traffic. The old Lujzijana or Louise Road was a more convenient tourism-market solution (the road itself is a tourism product) than the motorway (opened for traffic in 2008) which made transit traffic faster and provided no exit in the vicinity of the cave. Environmental issues may arise from the water reservoir constructed in 2008 and located above the elevation of the cave's entrance, as well as from increasingly intensive road construction (causing the disappearance of native landscapes).

Primarily a cavern, Vrelo Cave is part of the landscape created in the broader area of Fužine, the main features of which are Lake Lepeničko and Lake Bajer, and overregulated drainage. These changes to the landscape were brought about by the electric-power company "Elektroprivreda Hvratske". The cave has international standing. Because the floor of 


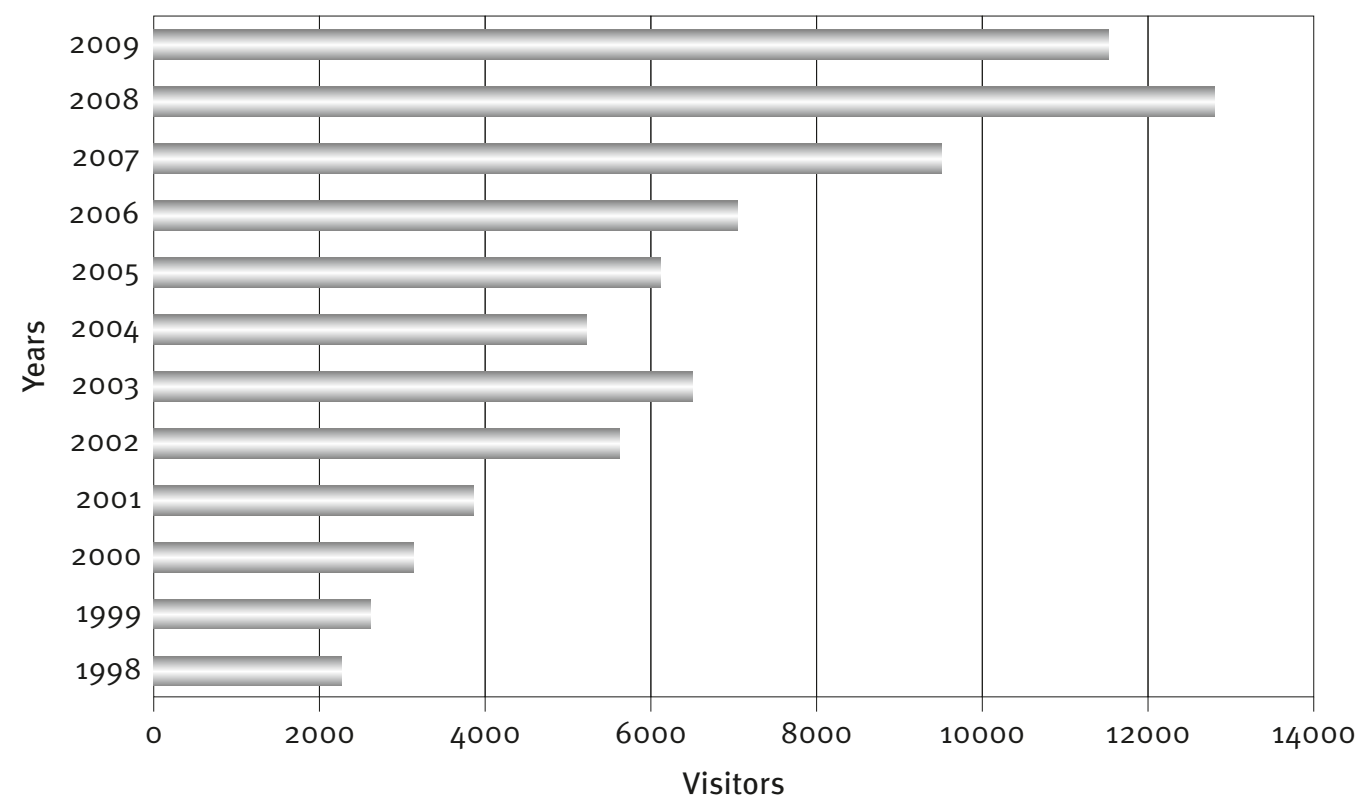

Figure 5 Vrelo cave - visitors 1998 - 2009

Source: Data of the Fužine Tourist Board

the cave is flat, disabled persons in wheelchairs can visit it. The cave is part of the tourism offering of Fužine, and this has proven to be vital it maintaining its sustainability. The link between tourism development in Fužine and increasing numbers of visitors to the cave is evident from the upwards trend of visitor numbers. The relative increase in tourist numbers is large, although in absolute terms, these numbers are low (Figure 5).

The position of Biserujka Cave is vital in maintaining its sustainability. Although the area of the cave open to the public (99 m) is shorter than that of Vrelo Cave (299 m) and, in particular, Lokvarka Cave (I,2OO m), Biserujka Cave boasts higher visitor numbers than either of the two caves.

Table I does not reflect daily visitor numbers in the best possible way (average daily visitor numbers amounted to 64 and 98 visitors in 2002 and 2007, respectively), as about $90 \%$

Table 1 Visitor numbers to Biserujka Cave

\begin{tabular}{|r|r|r|r|r|r|}
\hline Year & Adults & $\begin{array}{r}\text { Groups of } \\
\text { adults }\end{array}$ & Children & $\begin{array}{r}\text { Groups of } \\
\text { children }\end{array}$ & Total \\
\hline 2002 & 17309 & 356 & 3634 & 2165 & 23464 \\
\hline 2003 & 14703 & 330 & 3102 & 2567 & 20702 \\
\hline 2004 & 15680 & 1548 & 5907 & 3902 & 27037 \\
\hline 2005 & 17113 & 7156 & 888 & 2048 & 27205 \\
\hline 2006 & 24142 & 6740 & 675 & 2220 & 33777 \\
\hline 2007 & 22351 & 6621 & 3519 & 3091 & 35582 \\
\hline 2008 & 20917 & 5816 & 3255 & 2198 & 32186 \\
\hline 2009 & 17737 & 4954 & 2638 & 4725 & 30054 \\
\hline Total & 149952 & 33521 & 23618 & 22916 & 230007 \\
\hline
\end{tabular}

Source: Archives of Šiloturist Travel Agency 
visits occur in the summer months during the bathing season. ${ }^{11}$ The cave has the most visits during rainy days, when a day at the beach is replaced by other (lucrative) activities and services. $^{12}$ It can be concluded that Biserujka Cave is not a primary driving factor of tourist travel, but rather a consequence of the condition on the tourism market.

\section{Cave-tourism structures no longer operational}

Some sources of tourism data (Jemeršić, 2005) refer to the tourism-related and scientific importance that Bukovac Cave once had. The first relevant data were gathered by workers building the Zagreb-Karlovac-Rijeka railway (I87I - I873). The cave became the property of the Hungarian capital financing the construction of the railway. Research of the cave intensified in the early twentieth century when the archaeologist Theodor Kormoš discovered bones and tools in the cave dating to the Late Stone Age. ${ }^{13}$ Although Bukovac Cave, as an archaeological site, is constantly visited by day-trippers and researchers, it is poorly maintained and managed. ${ }^{14}$

Similarly, Hajdova Hiža Cave, one of the most attractive caves in the tourism offering of Gorski Kotar, has also been poorly valorised in terms of tourism. Located at a hard to access site, it is visited by adventure tourists using a speleological technique that has not changed in over 130 years. ${ }^{15}$ This fact is part of the problem as, throughout that time, no model has been applied that would ensure cave management and access to the cave.

Zamet Cave was important in educational purposes from I923 up to I977, when the cave roof threatened to collapse after bedrock blasting for the construction of a high-rise in the cave's vicinity. Although the cave was proclaimed a geomorphological monument of nature in I98I, devastation to the cave landscape has occurred frequently. A bottleneck in valorising Zamet Cave for tourism purposes has been caused by faulty planning and the failure of public administration bodies to accept responsibility.

Ice caves are a particular natural phenomenon. In terms of morphology, ice caves are pits in which snow and ice remain the year round. Unlike other pits that can form in any type of topographic conditions, ice pits form on northern exposures and at higher elevations above sea level. Sunlight never reaches the bottom of ice pits as the incident angle is constantly less than 90 degrees, and conduction, which is low in carbonate rock, does not cause the snow to melt (daily influences up to $60 \mathrm{~cm}$; annual, up to $8 \mathrm{~m}$ ). Because the snow does not melt, researchers believe ice caves to be relicts from the Pleistocene, making them all the more interesting.

In the period between the two World Wars, the Italians built cottages near the ice cave on Mount Jarmovac, where they would spend their nights after a day at the seaside. Advantage was taken of these recreational contrasts until the advent of air conditioning in the midtwentieth century.

${ }^{11}$ In statistics, visitor numbers are recorded on a calendar-year basis. Concession holders have provided estimates regarding seasonality.

12 Substitution such as this is not limited to Biserujka Cave. Baredine Cave, near Poreč, also sees more visitors on rainy days.

13 Artefacts date to the Late Stone Age, that is, the period when people lived in caves alongside animals. The artefacts are exhibited in the National Museum of Hungary in Budapest.

14 Most recent research conducted by the Archaeology Department of the Illinois State University (Bloomington).

15 This fact is based on a description of an ascent (dips, worn-out cables and handrails) made on IO May I885,in which Dragutin Hirc, travel writer and geographer (Hirc, I898) participated, as well as on a description of the cave in the booklet Staze $i$ šetnice published by the Delnice Tourist Board in 2009. 
During the heat of the summer, food and beverages establishments would take ice from the Pilar Ice Cave to cool drinks and beverages. Inns serving chilled beverages had a good reputation and attracted visitors. In recent times, only researchers visit ice caves, which have been completely neglected in the tourism offering.

\section{Submersed cave-tourism structures}

The Kvarner Bay is the cave-diving base of Primorsko-Goranska County. The bay's sea surface accounts for I4.2 \% of Croatia's coastal sea. More than half of the bay is located within the 4O-metre isobate, meaning that its water mass volume is not particularly large $(26.4$ $\mathrm{km}^{3}$ ). During the glacial period, Kvarner Bay was a shallow, karstic, land syncline that was flooded in the interglacial period. Speleological structures found in the seabed and sea coast are the result of eustatic sea level change. Marine sediments are fairly limited and do not present a restraining factor to cave tourists/divers (late Pleistocene Wurm-Holocene alluviation with limited muddy sediments). In general, diving conditions (illumination of the seabed and transparency, direction and speed of water currents, density, fresh-water submarine springs, pressure, salinity, the rate of immersion hypothermia) depend on the hydrodynamics of the water mass, and the Kvarner Bay has been rated as highly favourable in the diving tourism offering.

According to the Tourism Services Act (Official Gazette no. 68/O7) ${ }^{16}$, the Croatian Diving Association (CDA) is authorised to issue diving permits. The number of permits issued by the CDA has shown an upward trend over the years (in force since 1999), making diving tourism (of which cave - diving tourism is a part) a fast-growing form of tourism.

Cave diving in speleological structures in the seabed or sea coast of the Kvarner Bay is characterised by:

- a relatively large number of underwater structures of mostly small dimensions (Medvjeda Cave on the east coast of Lošinj island is the Bay's longest submersed cave, and the total length of its passages is 245 metres),

- cave entrances mostly located at a depth of 22 metres,

- diving in wide and easy-to-access tunnels,

- divers interested in finding and exploring siphons and dry parts of caves,

- a growing number of agencies holding concessions for various diving sites.

To a lesser extent, fully improving the quality of this promising branch of tourism is constrained by the lack of understanding of speleology by the institutions (tourist boards) that could become the potential providers of this offering.

\section{Potential cave-tourism structures}

An in-depth analysis of spatial relations and qualitative features leads to the conclusion that the Medvjeđa Cave, Golubinja Cave and Bukovac Cave near Lokve are structures that could become a part of the cave-tourism offering. The offering of these caves is not based on the length of their passages (individual lengths of up to 220 metres), but rather on the fauna dis-

16 The Draft Proposal of the Diving Act (2009) builds upon the Tourism Services Act (Official Gazette no. 68/O7). 
covered in them. Medvjeda (Bear) Cave is known for the bones and skull of Pleistocene bear (Ursus spelaeus) found in it. Although these bones are now exhibited in a Natural history museum in Vienna, many more bones still remain. Golubinja (Dove) Cave is named after the stockdoves that live in it. Medvjeđa Cave and Golubinja Cave, together with Bukovac Cave and Lokvarka Cave form a cave complex linked by a two-hour mountain-hiking isochrone. On the tourist market, these caves could compete jointly as a cave park, while each would represent a thematic whole (in terms of biospeleology, archaeology, etc.).

The speleological standards of the Zamet Cave and a concentration of tourism demand are justifications for its restructuring. The tourist market is located in the centre of an urban tourism region which attracts close to half a million customers in the tourist season. Providing the development concept could be tied to other potential service providers, the Zamet Cave could become an important business.

The tourist trade of Delnice should become a driver of the fuller valorisation of Hajdova Hiža Cave. The heterogeneous resources of Drgomalj could serve to fill the area between Delnice and the cave, and a path with a guard railing could be cut into the rock providing direct access to the cave.

\section{Vision of development and measures}

The proposal for measures to help develop cave tourism is based on an analysis of natural factors and social circumstances. In addition to unequivocal advantages, there are also limiting factors impeding market competition and the future development of cave tourism (Table 2).

In this paper, the scenario developed to valorise speleological structures relies on data gathered concerning the tourist-market position of cave tourism in Primorsko-Goranska County, the visitor attractions of these structures, and tourism superstructure (buildings, other facilities and services of the offering). Restructuring existing capacities and building new ones would be based on the support of institutions to projects, privatisation (concessions not shorter than 30 years) and joint investment. The level of appeal of all cave structures needs to be enhanced (through a plan for creating contrasts and diversity) by making changes to their interiors and building receiving facilities and services.

Development would be based on the design of a cave park at Lokve and the elaboration of project documents. Lokvarka Cave would continue to be the central location of the offering. Changes in the cave could be brought about by digging a passage (following the possible discovery of new caverns) linking the cave to the dry sinkhole of the Lokvarka River ${ }^{17}$. The entrance to the cave would remain in its present location, and the dry sinkhole would become the cave's exist. Such a scenario, mentioned for the first time in this paper, is known in the world and is applied when cave passages are narrow or an entrance needs to be made in an appropriate spot.

Stone-flagged paths and stairs connecting the caves and giving the entire area the features of a functional unit (park) would be located on a hypsometric plane ranging between 725 and 850 metres. The cave park would be open to visitors at all times, and Hajdova Hiža Cave, in agreement with the concession holder.

17 In I953, Elektroprivreda Hrvatske, the Croatian electrical energy company, diverted the waters of Lokvarka River from the Black Sea watershed to the Adriatic watershed. The distance between the lower galleries of Lokvarka Cave and the river's dry sink hole is some 50 metres. 
Table 2 SWOT analysis of the market position of cave tourism in Primorsko-Goranska County

\begin{tabular}{|c|c|}
\hline STRENGTHS & WEAKNESSES \\
\hline $\begin{array}{l}\text { - traffic position and accessibility } \\
\text { - tradition and knowledge in tourism development } \\
\text { - cave heritage } \\
\text { - archaeological site } \\
\text { - qualified work force } \\
\text { - conserved environment }\end{array}$ & $\begin{array}{l}\text { - out-dated offering } \\
\text { - lack of lucrative facilities and services } \\
\text { - poor marketing } \\
\text { - threatened cave ecosystems } \\
\text { - insufficiently utilized capacities } \\
\text { - unbalanced regional development }\end{array}$ \\
\hline OPPORTUNITIES & THREATS \\
\hline $\begin{array}{l}\text { - national strategy focused on developing special interest } \\
\text { tourism } \\
\text { - opportunities for improving the existing tourism product } \\
\text { - year-round operation } \\
\text { - incentive for developing other forms of special interest } \\
\text { tourism } \\
\text { - penetrating new markets } \\
\text { - strengthening entrepreneurship } \\
\text { - new jobs for residents }\end{array}$ & $\begin{array}{l}\text { - international competition (in particular, Škocijanska } \\
\text { Cave and Postojna Cave) } \\
\text { - lack of interested investors } \\
\text { - unchecked construction } \\
\text { - centralised management of natural resources } \\
\text { - depopulation } \\
\text { - no protection provided to archaeological sites and } \\
\text { dripstone formations } \\
\text { - lack of local initiative }\end{array}$ \\
\hline
\end{tabular}

The ice caves would retain an educational feature and would become a factor of health tourism development. In the various topographic sections in scale of I:50,000 published since I87I till I956, 28 ice-caves can be found. The microclimate conditions of these ice caves are uniform (low content of particles in the air, which is free of allergens and agents of disease; constant temperature and low humidity; specific $\mathrm{CO}_{2}$ concentration), and could be utilised in treating chronic and allergy-based respiratory disorders. The method of natural healing that takes advantage of cave conditions is called speleotherapy. Although practised in a number of countries, it is applied neither in Croatia nor in South Eastern Europe.

One of the strengths of Zamet Cave, which sets it apart from other caves, is its urban location. Location can be a key factor in developing private and public sector relationships and interest, including funding. In broad terms, projects would focus on developing services and facilities to enable year-round tourism and hospitality operations.

Over the past decade, Biserujka Cave has influenced the architecture of a number of buildings, which do not blend well with the town's tourism identity. Architecture should reflect the rural landscape, and the area surrounding the cave should become an ethno park. The park would focus on presenting the rural economy of Krk Island, in particular, native animal species, various forms of drywalls, wells, cultivated fields, pastures, as well as logging and forest management. This would help to broaden the cave offering, and the facilities constructed would not be incongruous with the natural landscape.

Unlike other types of special interest tourism that have a seasonal character, cave-diving tourism is a year-round activity.Compiling a register of underwater caves in the Kvarner Bay is a slow process, and, as such, it makes marketing more difficult and keeps the number of divers from growing at a faster rate.

Cave divers cite cumbersome red tape prior to diving and frequent changes in rules as weaknesses of cave-diving tourism.

Despite such weaknesses, Primorsko-Goranska County has succeeded in developing a method for rescuing, and providing assistance to, divers in distress (the Hypobaric Centre for the Kvarner region is located in Pula). The safety and security of cave divers are an important advertising basis. 


\section{Conclusion}

The carbonate system of Primorsko-Goranska County, together with geomorphological processes has conditioned the development of karstic relief. An environmental approach to many spheres of life has endowed karst tourism with a new meaning. The condition and development of cave tourism are examined within this context.

There is no uncertainty considering development opportunities, as cave tourism has been evolving in the territory of Primorsko-Goranska County since the second half of the nineteenth century, and visits to caves have been organised since I9I2. It can be concluded that about $25 \%$ of cave tourism capacities have been valorised for tourism purposes, meaning that there are large opportunities for development. Visitor numbers and revenue can be increased by repositioning the cave-tourism product and enhancing the offering with new facilities and services. The most rational way to go about doing this would be to concentrate new facilities and services in the cave-tourism offering of Lokve, reconstruct Biserujka Cave, and reopen Zamet Cave to the public.

Diving technology in show caves is linked to a variety of services, and an increase in diving-tourism traffic will help to create new jobs. The same applies to speleotherapy, a completely new branch of health tourism that could be developed in the ice caves of the County's mountain region.

\section{References}

Blažević, I., Knežević, R. (2006). Tourism Geography of Croatia, Faculty of Tourism and Hospitality Management, Opatija. (In Croatian)

Bočić, N. (2005). Water in Caves, Portal, geografija.hr (In Croatian)

Božić,V. (I999). Cave Tourism in Croatia: A Guide to Show Caves, Ekološki glasnik, Zagreb. (In Croatian)

Hirc, D. (I898). Gorski kotar (I3609), Zagreb.

Jemeršić, I. N., (2005). By Land and By Sea to the Plitvice Lakes, reprint, Matica hrvatska, Čabar. (In Croatian)

Kovačević, T. (2003). Baraćeve Caves, Rakovica Tourist Board, Rakovica. (In Croatian)

Matas, M. (2009). The Croatian Karst: Geographical Overview and Importance, Geographical society Split, Zagreb. (In Croatian)

Petrović, A. (2006). Cave Tourism in Serbia: Condition and Outlook for Development, PMF Proceedings - Institute of Geography, Belgrade, No. 54, I83-I94.

Resende, M. (2005). Cavidades naturais subterrâneas: patrimônio cultural brasileiro? Informativo SBE.Campinas, n. 90, 24-27.

Žanetić, J. (2009). Caves in Croatia Used in Tourism Purposes, Department of Geography, University of Zadar, Zadar. (In Croatian)

\section{Sources}

All-Asia touristic, Spezialist für Individualreisen in Asien und Lateinamerika: Rundreisen, Hotels, Flüge im Baukastensystem.

Archives of Šiloturist Travel Agency 
http://www.kyrgyzjer.com/en/Tourism/section

http://www.russiantraveller.ru/extrim-i-priklyucheniya/speleoturizm-v-rossii.aspx

National Caves Association, (2OIO). Cave Science, Park City, KY.

Draft of the proposal of the Diving Act (2009). Republic of Croatia, Ministry of the Sea, Transport and Infrastructure, Zagreb

Basic geological map, (1985). Legend

Rubinić, J. (20O4). Istraživanje međugraničnih vodonosnika s područja Jadranskog sliva Hrvatske i Slovenije - hidrološka obrada (Studying Cross-border Aquifers in the Adriatic Watershed of Croatia and Slovenia - A Hydrological Analysis), Faculty of Civil Engineering of Rijeka, Rijeka (internal).

Travel Romania, Romanian Monasteries - Travel Romania, 2OIO

Delnice Tourist Board (2009). Staze i šetnice (Footpaths and Trails), Rijeka

Karlovac County Tourist Board (2009): Aktivni odmor u Karlovačkoj županiji (Activity Holidays in the Karlovac County), Karlovac

Fužine Municipality Tourist Board

Lokve Tourist Board

wikipedia.org/wiki

Act on Providing Services in Tourism (Official Gazette No. 68/O7)

Act on Providing Services in Tourism (Official Gazette No. 68/o7) 